\title{
LAND-USE PRACTICES IN OURO PRETO DO OESTE, RONDONIA, BRAZIL
}

\author{
M.A. PEDLOWSKI AND V.H. DALE \\ Environmental Sciences Division \\ Publication No. 3850
}

Date Published - September 1992

Prepared by the

OAK RIDGE NATIONAL LABORATORY

OAK RIDGE, TENNESSEE, 378731-6038

Managed by

MARTIN MARIETTA ENERGY SYSTEMS, INC.

for the

U.S. DEPARTMENT OF ENERGY

under contract DE-AC05-84OR21400 
LIST OF FIGURES $\ldots \ldots \ldots \ldots \ldots \ldots \ldots \ldots \ldots \ldots \ldots$

LIST OF TABLES $\ldots \ldots \ldots \ldots \ldots \ldots \ldots \ldots \ldots \ldots \ldots \ldots \ldots$

ABSTRACT $\ldots \ldots \ldots \ldots \ldots \ldots \ldots \ldots \ldots \ldots \ldots \ldots \ldots \ldots$ viii

1. INTRODUCTION $\ldots \ldots \ldots \ldots \ldots \ldots \ldots \ldots \ldots \ldots \ldots \ldots$

2. METHODS $\ldots \ldots \ldots \ldots \ldots \ldots \ldots \ldots \ldots \ldots \ldots \ldots \ldots \ldots \ldots \ldots \ldots$

2.1 AREA OF STUDY $\ldots \ldots \ldots \ldots \ldots \ldots \ldots \ldots \ldots \ldots \ldots \ldots \ldots \ldots$

2.2 DATA GATHERING $\ldots \ldots \ldots \ldots \ldots \ldots \ldots \ldots \ldots$

3. RESULTS ........................ 7

3.1 THE CHARACTERISTICS OF THE COLONIST

AND CONFIGURATION OF LOTS $\ldots \ldots \ldots \ldots \ldots \ldots \ldots 7$

3.2 LAND-USE HISTORY $\ldots \ldots \ldots \ldots \ldots \ldots \ldots \ldots \ldots \ldots$

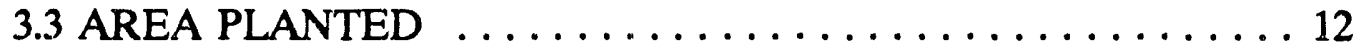

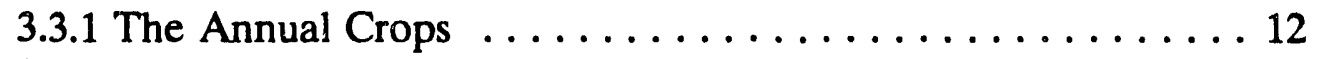

3.3.2 The Perennial Crops ...................... 13

3.4 PASTURE AND ANIMALS RAISING $\ldots \ldots \ldots \ldots \ldots \ldots \ldots 14$

3.4.1 The Area with Pasture .................... 14

3.4.2 The Animals Being Raised ................. 15

3.5 PRODUCTION AND COMMERCIALIZATION $\ldots \ldots \ldots \ldots 16$

3.5.1 Annual Crops . . . . . . . . . . . . . . . . . . 16

3.5.2 Perennial Crops . . . . . . . . . . . . . . . . . 16

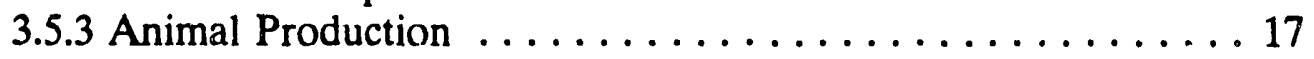

3.5.4 Lots Without Any Commercialization

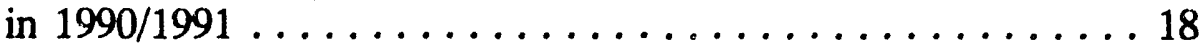

3.5.5 Distance and Markets Where the

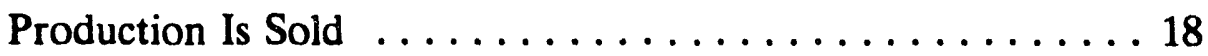

3.5.6 The Transportation ..................... 20

3.6 INCOME AND EXPENSES $\ldots \ldots \ldots \ldots \ldots \ldots \ldots \ldots \ldots 20$

3.6.1 Income from Perennial and Annual

Crops ..........................20

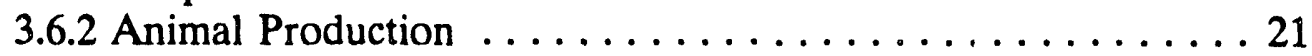

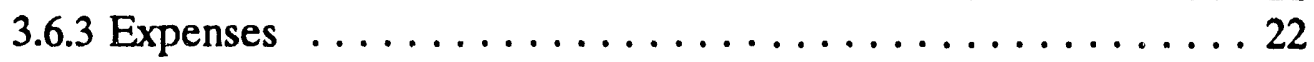


CONTENTS (continued)

3.7 THE COLONISTS AND THE GOVERNMENTAL

SUPPORT ........................ 24

3.7.1 Institutions of Research and

Technical Support .....................24

3.7.2 Public Services ...................... 25

4. SUMMARY AND CONCLUSION $\ldots \ldots \ldots \ldots \ldots \ldots \ldots \ldots$

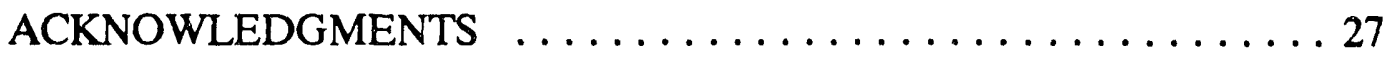

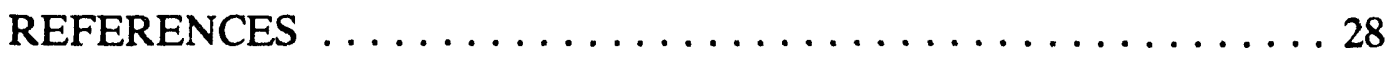

APPENDIX: Interview Form $\ldots \ldots \ldots \ldots \ldots \ldots \ldots \ldots \ldots \ldots \ldots$ 


\section{LIST OF FIGURES}

Figure

Page

1 Map showing Rondonia, the PIC Ouro Preto and PAD Urupá ... 4

2 Map of soil suitability (DNPM/RADAMBRASIL 1978) superimposed on the road network for the study area $\ldots \ldots \ldots \ldots \ldots \ldots 6$ 


\section{LIST OF TABLES}

Table

Page

1 Age of the colonists and population in the lots sampled ......8

2 Last location before arriving in Rondonia ............ 9

3 Previous occupations of the colonists $\ldots \ldots \ldots \ldots$

4 Area of deforestation (ha), days spent to clear the land, and kinds of labor available $\ldots \ldots \ldots \ldots \ldots$

5 Area planted with pasture, annual crops and perennial

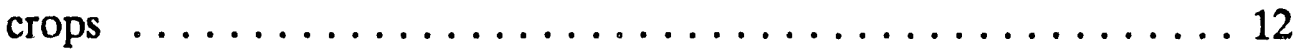

6 Area planted and average, maximum, and minimum per lot for annual

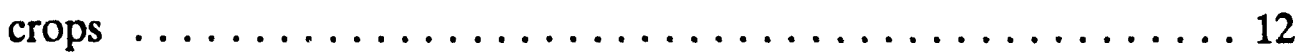

7 Area planted and average, maximum, and minimum per lot for

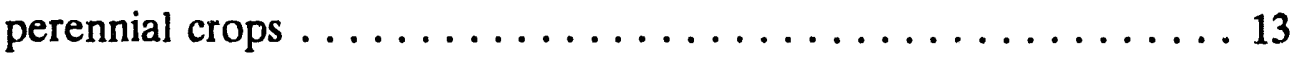

8 Total area and average, maximum, and minimum size per lot

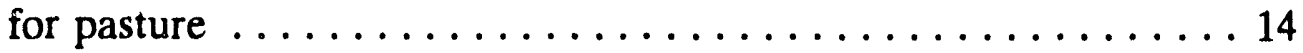

9 Total number of animals and average, maximum and minimum for

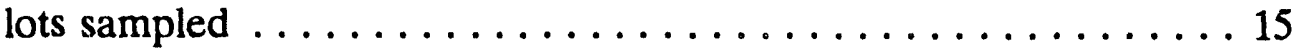

10 Area planted with annual crops, production, and commercialization $\ldots \ldots \ldots \ldots \ldots \ldots \ldots \ldots \ldots \ldots \ldots \ldots \ldots \ldots \ldots$

11 Area planted with perennial crops, production, and commercialization $\ldots \ldots \ldots \ldots \ldots \ldots \ldots \ldots \ldots \ldots \ldots \ldots \ldots \ldots$ 


\section{LIST OF TABLES (continued)}

12 Production and commercialization of milk during the dry

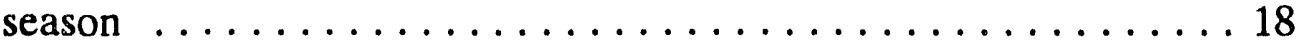

13 Commercialization of cows, pigs, and chickens in $1990 \ldots \ldots$. . . . 18

14 Distance from the lots to Ouro Preto and Ji-Paraná by paved

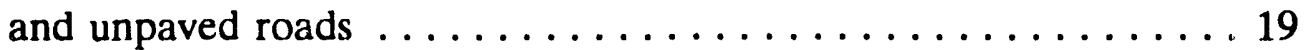

15 Markets where the production is commercialized $\ldots \ldots \ldots \ldots$

16 Forms of production transportation $\ldots \ldots \ldots \ldots$

17 Income (US \$) in 1990 from perennial and annual crops in terms of total, average, maximum and minimum incomes, and number of colonists selling each crop $\ldots \ldots \ldots \ldots \ldots \ldots \ldots \ldots \ldots \ldots \ldots \ldots \ldots \ldots$

18 Income (US \$) from animal production in terms of total, average, maximum, and minimum incomes, and number of colonists selling each item in $1990 \ldots \ldots \ldots 22$

19 Annual expenses (U.S. \$) to make the lots

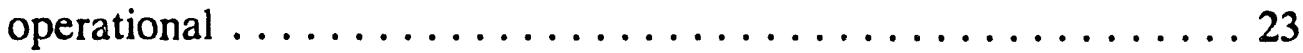

20 Scientific and rural extension support received by the colonists from governmental institutions $\ldots \ldots \ldots 24$ 


\begin{abstract}
Road development and colonization projects have brought about widescale deforestation in the Brazilian Amazon. The state of Rondonia, located in the western Amazon Basin, best exemplifies the problems related to landuse changes because it has the highest rates of deforestation in the Amazon Basin.
\end{abstract}

In order to identify the main land-use practices in Rondonia, interviews with local farmers were carried out in the central part of Rondonia, in the PIC (Integrated Colonization Project) Ouro Preto do Oeste. This is the oldest colonization project in the state. The governmental colonization programs attracted migrants to the area through the construction of roads and infrastructure necessary for the colonists to occupy the land for agricultural practices. The interviews were done on lots of the PIC Ouro Preto and in PAD Urupa to define the background of the colonists, their land-use practices, their economic situation, and their relationships with governmental institutions.

The results show that after 20 years, the colonists still face major obstacles to reaching a stable situation on the land. The only services available are elementary schools and health care, but both are provided only in a restricted way and leave the colonists under acute problems of lack of infrastructure.

Deforestation affected more than $50 \%$ of the area studied. Natural conditions (e.g., soils with low fertility, a strongly marked rainy season), the main land-use practices (e.g., "slash and burn agriculture," the absence of modern and appropriate techniques for the region), and the lack of governmental support (technical assistance, policy of storage and prices) caused a high turnover in the ownership of the land.

As a result, annual and perennial crops were replaced by pasture and cattle raising as the main source of income for the colonists in the region. 


\section{INTRODUCTION}

The occupation of the Amazon Basin has been a goal of Brazilian governments since the 19 th century. The region has the largest tract of tropical rain forest in the world [ > than 3.3 million $\mathrm{km}^{2}$ (Molofosky et al. 1986)], and a variety of mineral resources can be found there (Santos 1983). This combination of resources has led to the transformation of the region into the "last Brazilian frontier." During the 20th century the government has attempted to obtain a more complete control of the region and its resources (Machado 1991).

In 1970 the central government established the National Integration Program (PIN) as a result of economic tension in various regions of Brazil. The goal was to protect the western borders through the concentration of Brazilian citizens there. PIN was based on a new transportation system, the largest road of which is the Transamazon, to link the Atlantic coast to the Peruvian border. The goal of the project, which began in 1974 , was to settle 100,000 families $(500,000$ people) in 5 years along the Transamazon Highway (Jordan 1987, Fearnside 1986). However, by 1978, 4 years after the plan was originated. less than $8 \%$ of the anticipated number were settled. Several factors contributed to the failure of the Transamazonian colonization. The main problems involved failure to provide land titles, lack of secure loans for agricultural provisions, inadequate governmental support (e.g., absence of storage facilities and technical assistance), poor maintenance of roads, and the inability of the underlying forest soils to sustain agiculture.

The Brazilian state of Rondonia in the western Amazon Basin best exemplifies problems related to land-use changes. Anaiysis of the images generated by the AVHRR satellite for Rondonia shows that in $1980>8,000 \mathrm{~km}^{2}$ of forest were eliminated, increasing to $28,000 \mathrm{~km}^{2}$ by 1985 , and the total reached $41,000 \mathrm{~km}^{2}$ by 1987 (Malingreau and Tucker 1988, Stone et. al. 1991).

In contrast to the Transamazon development project, central Rondonia was situated on relatively good soils, and the plan included the establishment of some infrastructure. The colonization projects between 1970 and 1990 have successfully attracted migrants to the state through the construction of roads and infrastructure. The paving of BR-364 from Cuiabá to Porto Velho in 1984 played an important role in the 
arrival of colonists in the region, because it served as a corridor for year-round immigration. An increase in the number of immigrants, coupled with an increase in the area of accessible forest, had a strong effect on the amount and rate of deforestation (Frohn et al. 1990).

A direct relationship exists between increases in the paved roads and deforestation caused by the land-use practices of colonists arriving in Rondonia (Fearnside 1983, Leite and Furley 1985). The colonists usually cut down the forest, practice "slash and burn" agriculture of annual crops for a few years, and then turn the land to pasture which is burned annually (Coy 1987). The land becomes so degraded by agricultural use that it will not sustain cattle ranching or any other type of farming (Millikan 1988). These landuse practices increased the area of deforestation and caused dramatic alteration in the biodiversity of the region.

To identify the main land-use practices in Rondonia, interviews with colonists were carried out in the central part of the state, in PIC Ouro Preto and in PAD Urupá. The interviews were conducted with four goals in mind:

1. To define the social characteristics of the colonists, the different kinds of land use, the crops planted, the fate of the production, and the relationships between the colonists and governmental institutions.

2. To determine the influence of such variables as distance to the market, characteristics of the road network, and soil quality on the success or failure of the colonists.

3. To determine trends in land-use practices and their effects on deforestation.

4. To estimate future trends of land-use based on economic activity related to agriculture and cattle raising. 


\section{METHODS}

\subsection{AREA OF STUDY}

The PIC Ouro Preto and PAD Urupa are located in the central area of Rondonia (Fig. 1). The BR-364 is the only paved road in the region and connects Ouro Preto to cities in northern Rondonia as well as to Mato Grosso. The side roads are unpaved, which impedes passage during the rainy season. The topography in the region is dominated by low hills, averaging $340 \mathrm{~m}$. The analysis of land suitability by the DNPM/RADAMBRASIL (1978) for annual and perennial crops and pasture includes fours categories: good, moderate, restricted and unsuitable. The general descriptions were given as follows:

Good-Conditions present no to light limitations for a large number of crops that are climatically adapted. Good yields are expected for a period of 20 years, when the yields start to decrease gradually.

Moderate-Conditions present light to moderate limitations for a large number of crops that are climatically adapted. Good yields are expected for the first 10 years, and the yields are expected to decrease to a medium level during the following 10 years.

Restricted-Conditions present moderate to strong limitations for a large number of crops that are climatically adapted. Medium yields can be expected for the first few years, but they will decrease rapidly within a period of 10 years.

Unsuitable- Conditions present very strong limitations for farming a large number of crops that are climatically adapted, and yields are expected to be very low beginning in the first year of farming.

The study area is composed primarily of soils classified as good, but soils range from moderate to unsuitable for either annual or perennial crops and range from good to restricted for pasture.

The vegetation is characterized by dense tropical forest and the open tropical forest (DNPM/RADAMBRASIL 1978). Dense forest is stratified into basically four layers dominated by large trees with emergent canopies. The trees have luxurious 
AGRICULTURAL SUITABILITY IN OURO PRETO
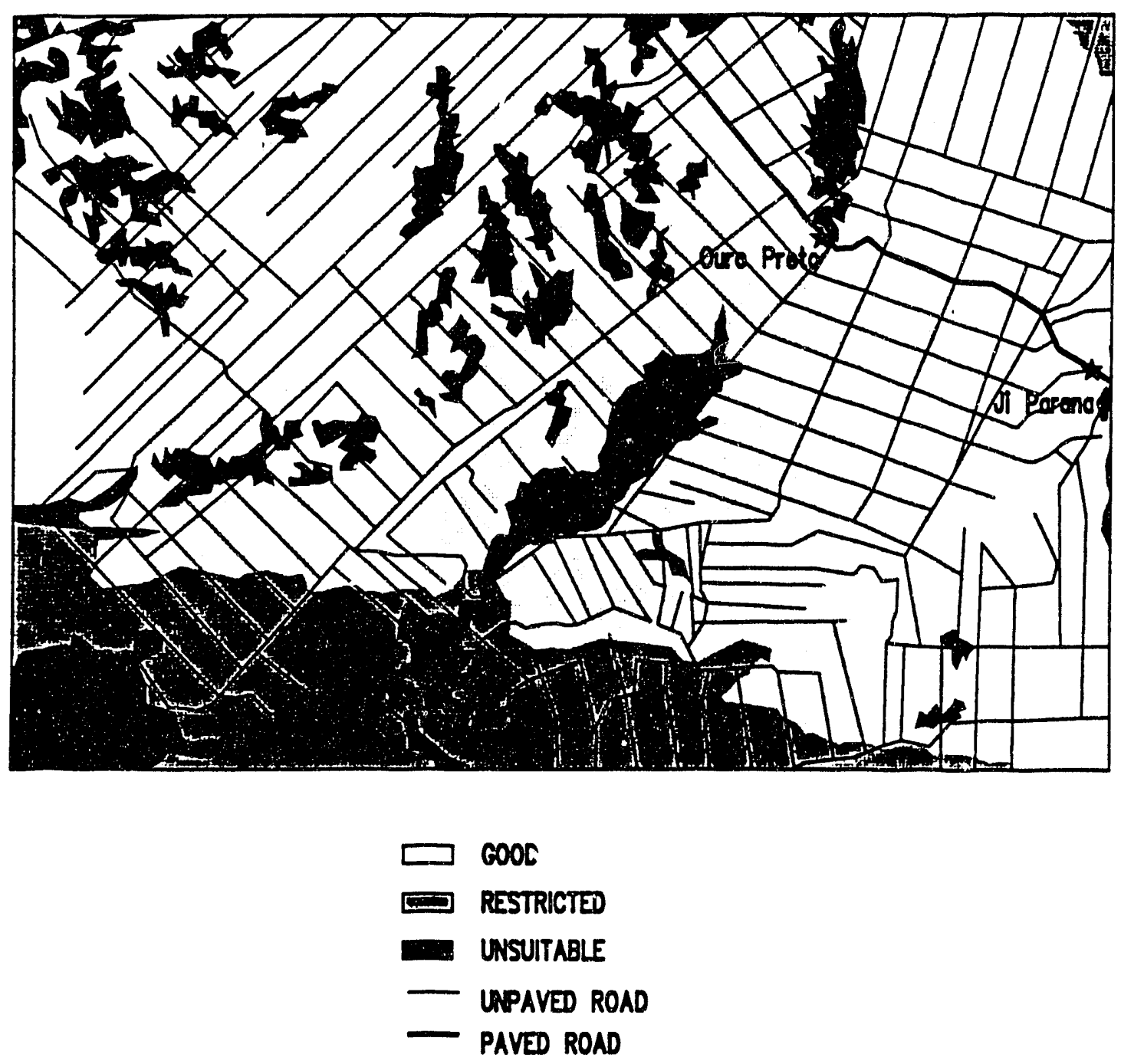

Fig. 1. Map showing the state of Rondônia, PIC Ouro Preto, PAD Urupá, and BR-364. 
canopies and tall, straight stems. The open forest is characterized by a dense mixture of palms. The palms can be present in homogeneous groups but can also appear mixed with species from the dense forest.

The region has two marked sessons: the rainy period occurs from November to April, and the area is dry the rest of the year.

\subsection{DATA GATHERING}

Interviews with farmers were determined to be the most practical method to obtain information about social characteristics, land-use patterns. influences, and trends. In preparation for the interviews, a questionnaire was created to obtain specific information about land-use practices (see Appendix).

The farms from which the colonists were interviewed were chosen on the basis of two variables: soil quality and distance to market. With the use of a $(1: 250,000)$ map of agricultural and pasture suitability and roads network (Fig. 2), colonists were selected to represent all combinations of soil suitability and distance. Within this framework a random subset was chosen.

The questionnaire in 'ludes colonists' demography, pattern of land use, productivity of the land, and the influence of official institutions of research and rural extension. Seven topic areas were included in the questionnaire:

1. Personal and family characteristics, their origin and prior occupations, the forms of land acquisition and reasons for choosing the specific lot, the number of lots previously occupied, and the main problems during the first occupancy of the lot.

2. Spatial characteristics of the lot, such as distance to the market, pavement characteristics of road network, and soil quality.

3. Rate of conversion from natural vegetation to crops or pasture, number of persons involved in clearing, the participation of different laborers (family and nonfamily) in this process, time spent, and kinds of tools used.

4. Information about the lot operation, such as mechanized and/or hand equipment, animals, teams of animals with operator, purchased seeds, fertilizers, insecticides, herbicides, labor, and structural. 


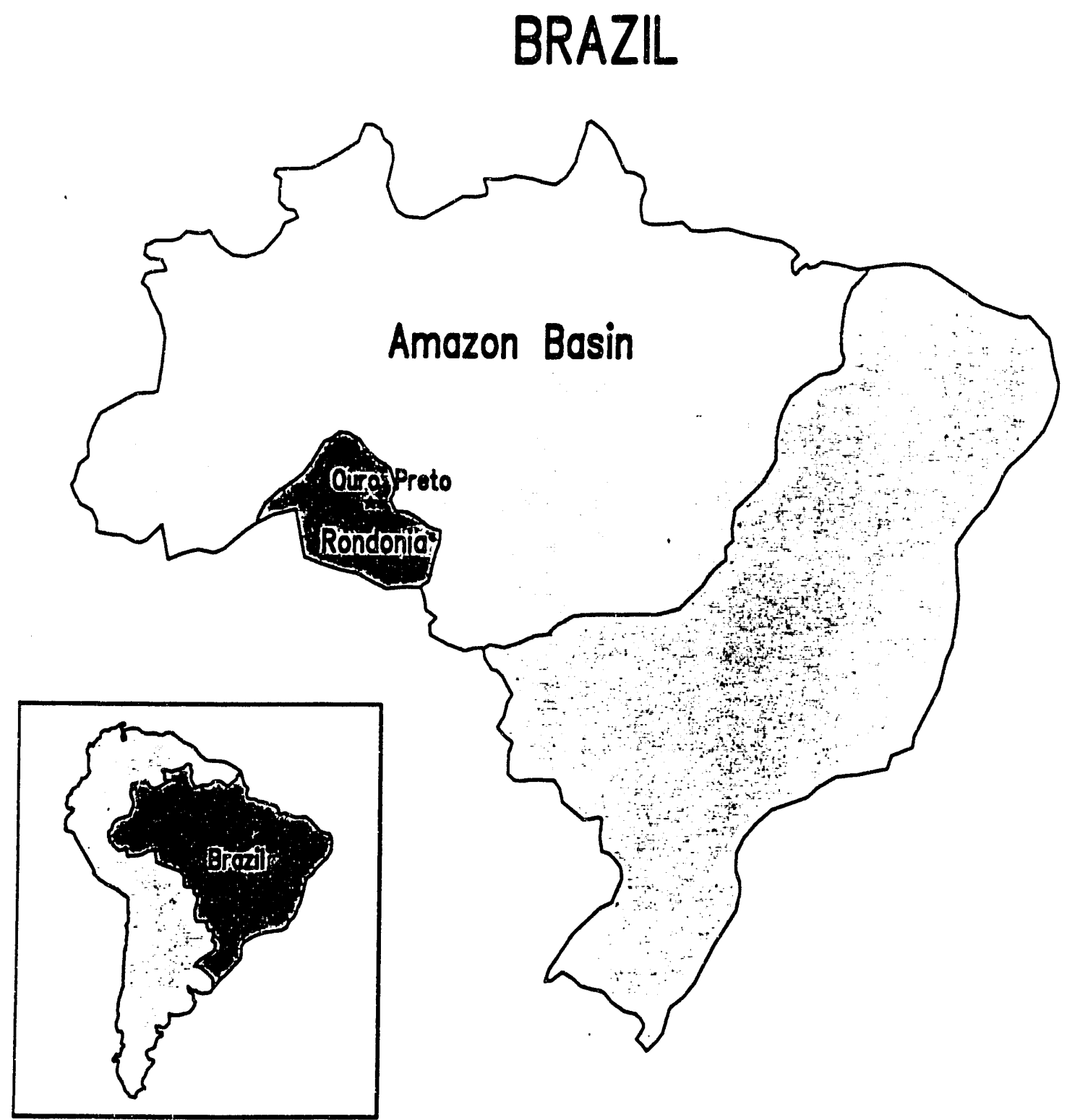

Fig. 2. Map of soil suitability (DNPM/RADAMBRASIL 1978) superimposed on the roads network for the study area. 
5. Areas planted (annual, perennial, and pasture), cattle raising, goods and animal production, amount of commercialization, kinds of transport used.

6. Technical support by governmental institutions [i.e., Brazilian Enterprise of Agriculture and Cattle Raising Research (EMBRAPA), Brazilian Enterprise of Rural Extension (EMATER), Brazilian National Council for Cocoa Cropping Development (CEPLAC), Urban Nucleus of Rural Support (NUARs)] and the main necessities required to make their lots viable.

A total of 86 interviews were carried out from August 6 to August 21 and from November 22 to December 6, 1991. Information was obtained about 91 lots. The difference between the number of interviews and the number of lots occurs because three wlonists had more than one lot in different locations. Fifty-five lots were sampled during the dry season and thirty-six during the wet season. Because milk production doubles during the wet season, the production values obtained during November and December were halved to provide a uniform comparison to dry-season milk production. The income found is expressed in U.S. dollars (U.S. \$) for November 1990, and milk and expenses were calculated in July 1991.

\section{RESULTS}

\subsection{CHARACTERISTICS OF COLONIS $\$$ AND CONFIGURATION OF LOTS.}

The total area of the 91 lots is 7,855 ha. The average is 86 ha; the range is from 5 to 288 ha. This variation in lot size illustrates three common situations: the preservation of the original size (100 ha), aggregation of one or more adjacent lots, and fragmentation of a given lot into smaller lots.

Coy (1987) observed that aggregation and fragmentation result from different reasons. Aggregation reflects either colonists who have done well on their original lots or the arrival of migrants with capital to buy a set of lots. Fragmentation is caused by a farmer's need to sell part of his lots to make the remaining viable. In contrast with the official planning, the region is currently undergoing extensive aggregation, especially adjacent to the BR-364, where some colonists are buying as many as 20 lots to use as 
pasture. However, this process is difficult to measure because the owners are not living on the lots.

The first colonists arrived in 1971 shortly after the establishment of the PIC and the paving of the road. During the 1970 s, $58 \%$ of the colonists arrived, primarily during the first half of the decade.

As shown in Table 1, the average age of the interviewed colonists, who ranged in age from 19 to 73 years, i 48.8 years. A total of 699 persons live on the 91 sample lots, including the colonists' families and sharecroppers.

Table 1. Age of the colonists and population on the lots sampled

\begin{tabular}{ccccc}
\hline & Age & Men & Women & Children \\
\hline Total & & 245 & 196 & 258 \\
Average & 48.8 & 3 & 2 & 3 \\
Maximum & 73.0 & 7 & 8 & 15 \\
Minimum & 19.0 & 0 & 0 & 0 \\
\hline
\end{tabular}

Most of the colonists immigrated from southern and southeastern Brazil: $23 \%$ were from the middle west, and only $4 \%$ were from the north or northeast (Table 2). The last place inhabited is not necessarily the colonist's birthplace because the person may have moved several times before arriving in Rondonia. The high percentage from the middle west had moved often because that area was recently settled and continues to have a high turnover rate. Only two colonists were originally from RondOnia. 
Table 2 Last location before arriving in Rondonia

\begin{tabular}{lc}
\hline Region & Relative frequency $(\%)$ \\
\hline South & 22 \\
Southeast & 50 \\
North & 2 \\
Northeast & 2 \\
Middle West & 23 \\
\hline
\end{tabular}

The colonists' previous occupations can be divided into seven categories (Table 3). The distinction between share renter and fixed renter is based on the percentage of production given to the owner (50\% in the first case) and the time spent on a certain area, which is longer for the second case. Most colonists were sharecroppers because the programs of the Brazilian government in the 1970s did not allow for the large number of landless farmers in other regions such as the south and southeast.

Land was acquired in two main ways. One-third (34\%) of the colonists received land from governmental programs in Ouro Preto, $64 \%$ bought the lot from other colonists, $1 \%$ changed lots to acquire a larger area, and $1 \%$ rented. Only $11 \%$ of the colonists were interested in selling their lots. Only $17 \%$ of the colonists had previously owned other lots in Rondonia. The low percentage of renters reflects a disinterest in renting land or having sharecroppers.

The length of time the colonists had been on the lots ranged from 0 to 20 years; the average time was 10 years. Browder (1990) found the same average for an area in the south of Rondonia. In the case of Ouro Preto, such results show that despite high turnover and soil degradation, the area is attractive to people searching for land. 
Table 3. Previous occupations of the colonists

\begin{tabular}{cc}
\hline Occupation & Relative frequency. (\%) \\
\hline Owner & 36 \\
Share renter & 39 \\
Fixed renter & 2 \\
Urban or town worker & 14 \\
Rural worker & 1 \\
Professional & 2 \\
Other & 6 \\
\hline
\end{tabular}

\subsection{LAND-USE HISTORY}

Table 4 shows deforestation during the first year on the land, the amount currently deforested, the annual average of days used to cut the vegetation, and the number of people involved in clearing (divided into family and nonfamily members). Current deforestation is $52 \%$ of the region (4,060.5 ha); an annual average of 3.1 ha is cut per lot. A total of 18 colonists never cut the natural vegetation, which reflects either a low level of activity or receipt of the lot totally cut up to the legal limit of $50 \%$.

Table 4. Area of deforestation (ha), days spent to clear the land, and kinds of labor available

\begin{tabular}{lcccccc}
\hline & $\begin{array}{c}\text { Cleared } \\
\text { first year } \\
\text { (ha) }\end{array}$ & Days to clear & $\begin{array}{c}\text { Family } \\
\text { workers } \\
\text { (no./farm) }\end{array}$ & $\begin{array}{c}\text { Non- } \\
\text { family } \\
\text { workers } \\
\text { (no./farm) }\end{array}$ & $\begin{array}{c}\text { Current } \\
\text { clearing } \\
\text { (ha) }\end{array}$ & $\begin{array}{c}\text { Area } \\
\text { cleared } \\
\text { per year } \\
\text { (ha/yr) }\end{array}$ \\
\hline Total & 423.4 & 2245 & 178 & 113 & 4060.5 & 282.8 \\
Average & 4.6 & 25 & 2 & 1 & 45 & 3.1 \\
Maximum & 24 & 115 & 10 & 10 & 180 & 15.4 \\
Minimum & 0 & 0 & 0 & 0 & 4 & 0 \\
\hline
\end{tabular}


The time of clearing averaged 24 days, ranging from 0 to 115 days. The wide range of days necessary is explained by the number of laborers, tools available, and the types of natural vegetation. Most laborers are family members (61\%).

Chain saws decreased the time spent in clearing and the number of people involved. Currently $74 \%$ of the farmers use chain saws plus other tools, and of this total $54 \%$ are chain-saw owners. The other farmers used only machetes and/or sickles.

The farmers estimate that a decrease in productivity has occurred on $57 \%$ of the lots. However, this decrease may be underestimated because of the colonists' lack of knowledge about land fertility. Specific crops (e.g., rice, corn, coffee, and cocoa) are in decline after some years of agricultural use.

Slash-and-burn agriculture is practiced every year by $62 \%$ of the colonists, and only $1 \%$ ( 1 colonist) declared that he had never burned. The remaining $37 \%$ burn less frequently. Small trees, vines, and understory are cut at the beginning of the dry season. Then the farmers wait until the slash is as dry as possible to ensure a complete burning. Burning provides ash to fertilize the land and eliminates large amounts of material that impede planting (Jordan 1987).

There are limited land preparation practices. Only $7 \%$ of the farmers -basically cocoa planturs who received financial support from CEPLAC - fertilize with manure. Liming is not practiced because the colonists are not aware of this kind of land preparation. On the other hand, 63\% of them annually rotate crops. The type of rotation commonly used is very rustic (first they plant rice and corn; afterward they plant beans), but the practice does reduce soil degradation. Unfortunately, an increasing trend is to substitute a more damaging rotation that consists of rice during one year and pasture in the following years.

The combination of soil limitations, land preparation, and availability of tools for clearing represents a crucial problem for the control of deforestation. As Frohn et al. (1990) pointed out, the potential for deforestation is greater than what has actually occurred, and the present results reinforce that conclusion. 


\subsection{AREA PLANTED}

Table 5 shows the area planted, divided into annual crops, perennial crops, and pasture. Pasture covers $72 \%$ of the area; $12 \%$ is in annuals, and $16 \%$ is in perennials.

Table 5. Area planted with pasture, annual crops, and perennial crops

\begin{tabular}{lcc} 
& $\begin{array}{c}\text { Relative frequency(\%) } \\
\text { Area planted } \\
\text { (ha) }\end{array}$ \\
\hline Total & 100 & $3,889.9$ \\
Annual & 12 & 464.0 \\
Perennial & 16 & 620.6 \\
Pasture & 72 & $2,805.2$ \\
\hline
\end{tabular}

\subsubsection{The Annual Crops}

The most common annual crops are rice, beans, corn, and manioc (Table 6). Percentiles total more than $100 \%$ because of the crop rotation used in the region. Beans are planted after rice and corn are harvested. The manioc is commonly planted among corn and beans, and the amount is difficult to determine because the colonists plant it in an uncontrolled way.

Table 6. Area planted and average, maximum, and minimum per lot for annual crops

\begin{tabular}{cccccc}
\hline & Total (ha) & $\begin{array}{c}\text { Number of } \\
\text { lots }\end{array}$ & $\begin{array}{c}\text { Average } \\
\text { (ha) }\end{array}$ & $\begin{array}{c}\text { Maximum } \\
\text { (ha) }\end{array}$ & $\begin{array}{c}\text { Minimum } \\
\text { (ha) }\end{array}$ \\
\hline Rice & 213.8 & 68 & 3.1 & 16.8 & 0.5 \\
Beans & 226.4 & 62 & 3.6 & 16.8 & 0.2 \\
Manioc & 43.5 & 35 & 1.2 & 4.8 & 0.2 \\
Corn & 325.3 & 74 & 4.4 & 24.0 & 0.5 \\
\hline
\end{tabular}

- From a total of 91 
Corn is presently planted more than other traditional food crops, and the persistence of this trend is linked with the increase in the area covered with pasture. To illustrate this situation, the current results can be compared with those of a study done by INCRA (1982) for the PIC Ouro Preto in which the areas planted to rice, beans, manioc, and corn were, respectively, $3.81,4.30,0.40$, and 3.90 ha. The values found in the 1991 interviews for the same crops are 2.3, 2.4, 0.4 and 3.6. Rice and beans are declining for different reasons.

Rice requires areas recently deforested, which are becoming rarer as a result of the legal restrictions. Beans are declining because they have been affected by diseases.

\subsubsection{The Perennial Crops}

The colonists were encouraged by financial programs to plant perennial crops, especially cocoa, rubber, and banana. However, the amount of coffee also increased in the region because the colonists came from coffee-growing areas.

Coffee is the most common perennial crop (Table 7) because cocoa and banana have been unproductive in recent years mainly as result of decreases in soil fertility, diseases, fungal outbreaks, and insects. Also, such crops as sugarcane and fruits have not been traditional, and colonists show little inierest in planting them. Some colonists indicated that even coffee is decreasing in productivity. Currently, there is a tendency to eradicate perennial crops from many areas.

Table 7. Area planted and average, maximum, and minimum per lot for perennial crops

\begin{tabular}{cccccc}
\hline & $\begin{array}{c}\text { Total } \\
\text { (ha) }\end{array}$ & $\begin{array}{c}\text { Number of } \\
\text { lots }\end{array}$ & $\begin{array}{c}\text { Average } \\
\text { (ha) }\end{array}$ & $\begin{array}{c}\text { Maximum } \\
\text { (ha) }\end{array}$ & $\begin{array}{c}\text { Minimum } \\
\text { (ha) }\end{array}$ \\
\hline Cocoa & 168.9 & 25 & 6.8 & 19.9 & 0.6 \\
Fruits & 6.3 & 05 & 1.2 & 2.4 & 0.5 \\
Coffee & 361.3 & 59 & 6.1 & 24.0 & 0.1 \\
Rubber & 55.2 & 07 & 7.9 & 12.0 & 1.2 \\
Banana & 36.6 & 12 & 3.0 & 7.2 & 1.2 \\
Sugarcane & 19.9 & 01 & 19.9 & 19.9 & 0.0 \\
\hline
\end{tabular}




\subsection{PASTURE AND ANIMAL RAISING}

\subsubsection{The Area with Pasture and Secondary Vegetation}

Pasture or secondary vegetation is absent from only $4.3 \%$ of the lots studied (Table 8). One reason is that land consolidation occurs through the transition from crops to cattle. This transition is caused by the decrease in crop productivity, by the problems in the storage or transport of the crops, and by the lack of a national policy of prices which makes income from crops very unstable. Thus, cattle raising and pasture represent a safer return on the money spent by farmers.

A second reason is that pasture is ronsidered an improvement in land conditions and thus increases the price of the property. As a result, having pasture can be helpful for those farmers wishing to sell the land. Planting pasture does not necessarily indicate interest in or even plans to have cows; $15 \%$ of the lots with pasture do not have any cows.

The conversion to pasture is happening at a rapid pace. Surveys in the earlier 1980 s found that land in pasture ranged from $40 \%$ to $49 \%$ in the lots of Ouro Preto (Leite and Furley 1985; Lena 1982; Coy 1987). The 1991 estimate of pasture area was $72 \%$ but included some secondary vegetation because farmers tended to lump the two categories. The area of pasture and secondary vegetation can be even higher because in the areas where aggregation has occurred, pasture is often the only land use. Thus, the trend toward pasture's attaining a complete dominance in the area will be reversed only if valuable and stable sources of income for the colonists are identified.

Table 8. Total area, average, maximum, and minimum size per lot for pasture (which may include some secondary vegetation)

\begin{tabular}{lc}
\hline & Hectares \\
\hline Total area & $2,805.2$ \\
Average & 32.2 \\
Maximum & 163.2 \\
Minimum & 0.6 \\
Number of lots & 87 \\
\hline
\end{tabular}




\subsubsection{The Animals Being Raised}

Table 9 presents the most important animals on the lots sampled. The commercial importance of cattle is evidenced by a total of 3,739 head, which represents an average of 41 head per lot. Even considering the high variance caused by different resources among the farmers, cattle are very significant to the region's future. About $68 \%$ of the cows are beef cows, and the remaining $32 \%$ are milk cows, which provide daily incomes from milk production.

Pigs are of secondary commercial importance, and chickens are raised more for subsistence than for sale. The pigs raised in the region belong to an inferior species with high fat content.

Table 9. Total number of animaks and average, maximum, and minimum for lots sampled

\begin{tabular}{lcccc}
\hline & Total & Average & Maximum & Minimum \\
\hline Milk cows & 1,200 & 13 & 120 & 0 \\
Beef cows & 2,539 & 28 & 172 & 0 \\
Pigs & 908 & 10 & 50 & 0 \\
Chickens & 7,565 & 83 & 400 & 0 \\
Sheep/goats & 94 & 2 & 58 & 0 \\
Ducks & 12 & 0.1 & 10 & 0 \\
\hline
\end{tabular}

Sheep and goats are still raised by a few farmers but may be important in the future because they easily adapt to the region. Ducks were found in only two iots and are not important even as a source of food. 


\subsection{PRODUCTION AND COMMERCIALIZATION}

\subsubsection{Annual Crops}

Table 10 shows the area planted with annual crops, their production, and sale. Compared with INCRA (1982), all crops experienced a decrease. Rice decreased 27\%; beans, $10 \%$; manioc, $32 \%$; and corn, $16 \%$. Only beans are largely commercialized (56\%), whereas rice (30\%), corn (20\%), and manioc (0\%) are mainly used for subsistence.

Table 10. Area planted with annual crops, production, and commercialization

\begin{tabular}{cccc}
\hline Crop & Area planted (ha) & Production & Sale \\
\hline Rice (60 kg bags) & 213.8 & 3,660 & 1,099 \\
Beans (60 kg bags) & 226.4 & 1,792 & 1,003 \\
Manioc (kg) & 43.5 & 211,000 & 0 \\
Corn (60 kg bags) & 325.3 & 6,955 & 1,179 \\
\hline
\end{tabular}

\subsubsection{Perennial Crops}

Table 11 shows the area planted with perennial crops, their production, and sale. The main ones are cocoa and coffee. The official financial support (provided by CEPLAC) gave more support for cocoa than coffee, but the colonists followed their traditions, and coffee is currently more important than the other perennial crops. Banana, rubber, fruits, and sugarcane cover only $19 \%$ of the area planted, and there is no indication that this pattern will change, because there is a lack of ñnancial support, technical support, and the price policies required to improve such crops as fruits, rubber, and banana. Perennial crops are more commercialized than annual crops because the colonists cannot use these crops as food. The exception is bananas, which are food for both humans and animals. Sugarcane is used to produce white rum.

Twenty-four lots (26\% of the sample) sell neither perennial nor annual crops. Furthermore, these lots have no bananas, cocoa, fruits, or rubber. Although there is no commercial production, crops profuced and used on the lot contribute $8 \%$ of the total production of corn ( $n=510$ bags), $9 \%$ of the total production of rice $(n=365$ bags), $2 \%$ 
of the total production of beans ( $n=32 \mathrm{bags}$ ), and $0.2 \%$ of the total production of coffee $(n=20$ bags). One colonist said he produced $90,000 \mathrm{~kg}$ of manioc (43\% of the total production declared). Other farmers undoubtedly grew manioc but did not have an estimate of the amount grown. The low level of activity in these 24 lots is related to the economical failure of farmers on soils of low fertility and to the expansion of cattle raising (half of the 24 lo's have profits from animal sales).

Table 11. Area planted, production, and sale of perennial crops

\begin{tabular}{cccc}
\hline Crop & $\begin{array}{c}\text { Area } \\
\text { plante. } \\
\text { (ha) }\end{array}$ & Production & Sale \\
& 168.9 & 33.600 & 33,600 \\
Cocoa (kg) & 36.6 & 7,310 & 4,710 \\
Banana (bunches) & 6.2 & 165 & 165 \\
Fruits (boxes) & 361.3 & 8,291 & 7,628 \\
Coffee (40 kg bags) & 55.2 & 6,272 & 6,272 \\
Rubber (kg) & 19.9 & 1,000 & 0 \\
Sugarcane (kg) & & & \\
\hline
\end{tabular}

\subsubsection{Animal Production}

Table 12 shows the production and sale of milk during the dry season. Of the lots sampled, $70 \%$ are producing milk, and $80 \%$ of the milk is sold to factories in Ji-Paraná and Ouro Preto. The remaining milk is for the production of cheese or for subsistence. The boom in milk production has caused improvements in the infrastructure, exemplified by the construction of a cheese factory and a second milk factory.

Despite the high number of lots covered with pasture, only a few colonists obtain a high return from animal production. Twenty-one percent of the lots are responsible for $62 \%$ of the produc ion and $77 \%$ of the sale of the animals. 
Table 12. Production and commencialization of milk during the dry season

\begin{tabular}{ccc}
\hline & Number of lots & Total (liters/day) \\
\hline Milk produced & 64 & 2,211 \\
Milk sold & 46 & 1,766 \\
\hline
\end{tabular}

In fact, $33 \%$ of the lots do not have any kind of income from animal production $(n=33)$, and $23 \%$ of the lots $(n=21)$ produce milk but do not sell it. The commercialization of other animals is shown in Table 13. The most important source of income is the revenue from beef cows, but only $30 \%$ of the lots benefit. Pigs were sold on $12 \%$ of the lots and chickens on $16 \%$ of the lots.

Table 13. Commercialization of cows, pigs, and chickens in 1990

\begin{tabular}{ccc}
\hline & Number of lots & Total \\
\hline Cows & 28 & 238 \\
Pigs & 11 & 117 \\
Chickens & 15 & 806 \\
\hline
\end{tabular}

\subsubsection{Lots Without Any Commercialization in 1990/1991}

Twelve lots had no income from either crops or animal production. These nonproductive lots are disastrous for the colonists who depend on the lot for survival. The lots either are in areas with poor soils or are far from the main road.

\subsubsection{Distance and Markets Where The Production is Sold}

Table 14 shows the distance to the main markets in the region. Ouro Preto is the closest market, and most colonists must travel unpaved roads to reach it. Mobility is greatly reduced during the rainy season, especially on tertiary roads. The average distance from the lots to Ji-Parana is two times higher, and the distance along unpaved roads is almost the same. Transportation is clearly a main obstacle for the absorption of production by Ji-Paraná. 
Table 14. Distance from the lots to Ouro Preto and Ji-Parana by paved and unpaved roads

\begin{tabular}{ccccc}
\hline Distance & \multicolumn{2}{c}{ Ji-Paraná } & \multicolumn{2}{c}{ Ouro Preto } \\
\cline { 3 - 5 } \cline { 3 - 5 } & Paved & Unpaved & Paved & Unpaved \\
Average & 33 & 36 & 4 & 34 \\
Maximum & 60 & 113 & 22 & 84 \\
Minimum & 0 & 0 & 0 & 0 \\
\hline
\end{tabular}

The NUARs (Urban Nucleus of Kural Support) are the second important market. The different levels of economic success found among the different NUARs occur because only some of them receive produce from the surrounding farms. Rondoninas and Vale do Paraiso, for example are centers of milk production which is trucked directly to factories in Ouro Preto and Ji-Paraná. Ji-Paraná, Jarú, Alvorada do Oeste, and Porto Velho are secondary markets; most of the goods are sold in Ouro Preto before they are transferred to the larger cities.

For some goods the primary market is outside Rondônia. In those cases truckers come from other regions of the country and buy produce directly on the lots.

Table 15. Markets where the production is commercialized

\begin{tabular}{ccc}
\hline Market & Sale of animal production & Sale of crops \\
\hline Ouro Preto & 44 & 49 \\
Nuar & 9 & 17 \\
Ji-Paraná & 10 & 6 \\
Jarú & 1 & 2 \\
Alvorada do Oeste & 1 & 0 \\
Porto Velho & 0 & 1 \\
Lot & 8 & 6 \\
\hline
\end{tabular}




\subsubsection{The Transportation}

Table 16 shows the main forms of transportation in the area. An important aspect is the lack of vehicles among the colonists, because only $3 \%$ of the colonists interviewed $(\mathrm{n}=3)$ own a truck. The colonists pay freight costs for having milk picked up daily from their lots. The expense amounts to $22 \%$ of the production. Thus, besides the low price paid for milk, the factories make money by transporting the milk in the factories' milk trucks.

Table 16. Forms of production transportation

\begin{tabular}{ccc}
\hline Vehicle & Milk & Crops \\
\hline Truck belonging to other person & 29 & 40 \\
Bus & 0 & 4 \\
Truck belonging to a colonist & 1 & 3 \\
Other & 8 & 2 \\
\hline
\end{tabular}

\subsection{INCOME AND EXPENSES}

\subsubsection{Income from Perennial and Annual Crops}

Table 17 shows the income from perennial and annual crops and the number of colonists benefitting from the sale of each crop. Coffee is the most important source of income and represents $64 \%$ of the total crop income. Beans are second in importance ( $9 \%$ of the income), but the number of colonists selling beans is lower. Cocoa represents 7\% of the total income. Other crops (rice, corn, fruits, banana, and rubber,) represent $11 \%$ of income and are sold by only a few colonists. The sale of white rum and honey provides the remaining income from crops.

Despite efforts carried out by governmental institutions to introduce perennial crops in the region, presently only three crops constitute $80 \%$ of the total income. In addition, all these crops suffer problems at different scales (e.g., loss of soil quality and diseases at the local scale and low prices at the national scale). 
Table 17. Income (USSS) in 1990 from perennial and annual crops in terms of total, average, maximum, and minimum incomes, and number of colonists selling each crop

\begin{tabular}{lccccc}
\hline & Total & Average & Maximum & Minimum & $\begin{array}{c}\text { Number of } \\
\text { colonists }\end{array}$ \\
\hline Rice & 10,957 & 577 & 2193 & 120 & 19 \\
Beans & 22,898 & 739 & 2625 & 68 & 31 \\
Corn & 6,532 & 502 & 1662 & 22 & 13 \\
Fruits & 69 & 34 & 50 & 19 & 2 \\
Coffee & 154,595 & 3,435 & 20,923 & 80 & 45 \\
Banana & 4,993 & 624 & 1,060 & 159 & 8 \\
Rubber & 4,617 & 1,154 & 4,335 & 23 & 4 \\
Cocoa & 17,136 & 857 & 3,060 & 10 & 20 \\
Others & 19,077 & 4,769 & 11,898 & 874 & 4 \\
\hline
\end{tabular}

\subsubsection{Animal Production}

The results demonstrate the importance of milk production as a source of income for the colonists (Table 18). The daily income averages $\$ 2$ (U.S.) during the dry season and decreases to around $50-70 \%$ thereafter. When this value is extrapolated for annual production, the total income from milk is second only to the sale of cows. Income from milk and beef are both less than the income provided by coffee. This helps explain the trend in substituting annual and perennial crops with animal production as the main source of income.

The sale of beef cows is of increasing importance for the local economy. It is the second most important source of income, and many colonists are interested in planting pasture. However, the number of colonists benefitting is restricted because only $31 \%$ sold cows during the past year. Only a few colonists obtain income from pigs or chickens. 
Table 18. Annual income (U.S. \$) in 1990 from animal production in terms of total, average, maximum, and minimum income, and number of colonists

\begin{tabular}{ccccc}
\hline & Milk production & Cows sold & Pigs sold & Chickens sold \\
\hline Total & 66,758 & 109,554 & 3,591 & 1,814 \\
Average & 734 & 3,913 & 326 & 121 \\
Maximum & 6,327 & 11,508 & 921 & 405 \\
Minimum & 38 & 460 & 31 & 14 \\
Number of colonists & 46 & 28 & 11 & 15 \\
\hline
\end{tabular}

\subsubsection{Expenses}

Operational expenses include land preparation (e.g., tools, labor), planting and weeding (e.g., seeds, herbicides, insecticides), vehicles (trucks, tractors), animals (e.g., cows, pigs, chickens), and improvements in infrastructure (e.g., houses, stables, fences) (Table 19). Obtaining these values was difficult because the colonists do not keep records.

The main form of expenses is the acquisition of animals, declared by $77 \%$ of the colonists to have reached a total of $\$ 447,848$ (U.S.). Most of this money was used to buy cows. Only $24 \%$ of the colonists were responsible for $70 \%$ of the expenses related to animals, which indicate a high concentration of capital among a few colonists.

Improvement in infrastructure is the second most important expense; with $82 \%$ of the colonists spending a total of $\$ 361,688$ (U.S.) on materials to build stables, fences, and houses and to buy motor pumps and chain saws.

The acquisition of vehicles is the third most important expense. However, only $20 \%$ of the colonists owned a motorized vehicle (tractor, truck, or car), and only $27 \%$ had a cart. 
Table 19. Expenses (U.S. dollars in July 1991) used to make the lot operational

\begin{tabular}{|c|c|c|c|c|c|}
\hline & Total & Average & Maximum & Minimum & $\begin{array}{c}\text { Number of } \\
\text { colonists }\end{array}$ \\
\hline $\begin{array}{l}\text { Motorized } \\
\text { vehicle }\end{array}$ & 136,476 & 7,183 & 34,624 & 120 & 19 \\
\hline Animal vehicle & 10,229 & 409 & .903 & 213 & 25 \\
\hline Animals" & 447,848 & 6,398 & 83,098 & 34 & 70 \\
\hline Manual tools & 4,576 & 53 & 112 & 5 & 86 \\
\hline Purchased seeds ${ }^{2}$ & 6,517 & 310 & 1,199 & 3 & 21 \\
\hline $\begin{array}{c}\text { Laborers (per } \\
\text { year) }\end{array}$ & 36,874 & 838 & 6,408 & 27 & 44 \\
\hline Fertilizers & 1,581 & 790 & 1,395 & 186 & 2 \\
\hline Infrastructure & 361,688 & 5,089 & 68,944 & 93 & 75 \\
\hline $\begin{array}{l}\text { Agricultural } \\
\text { defensive }\end{array}$ & 95,705 & 1,450 & 15,141 & 40 & 66 \\
\hline
\end{tabular}

Estimated over the time the farmer has been on the lot.

A significant number of colonists $(n=66)$ spent money on herbicides, insecticides, or medication for cows. The relative lack of money spent on fertilizers and purchased seeds shows that there is low interest in improving the land preparation quality. Only $2 \%$ of the colonists $(n=2)$ acquired fertilizers, and $11 \%$ bought seeds. Most of the colonists (95\%) spent money to acquire manual tools.

Contracted laborers were hired by $48 \%$ of the farmers for land preparation and periodic clearing. The ranchers have a more stable staff to handle their cattle and tend to establish a more stable labor market. 


\subsection{THE COLONISTS AND THE GOVERNMENTAL SUPPORT}

\subsubsection{Institutions of Research and Technical Support}

Few of the colsnists received any scientific contribution from EMBRAPA (91\% of the colonists) or CEPLAC (67\% of the colonists) (Table 20). CEPLAC assistance is higher because of the strong incentives to establish cocoa in Rondonia. But this role has decreased in recent years because of the national economic crisis and problems with international markets.

In contrast, half of the colonists received rural extension services from EMATER (the rural extension service) at least one time. In many cases, the staff of EMATER consists of poorly trained personal. Thus, prevailing agricultural practices are based on the empirical knowledge of the colonists. This contributes to the problems with land degradation because the colonists are largely from regions where a very different ecological situation exists.

Table 20. Scientific and rural extension received by the colonists from governmental institutions

\begin{tabular}{cccc}
\hline & EMBRAPA & CEPLAC & EMATER \\
\hline Never & 78 & 58 & 43 \\
Once & 5 & 5 & 3 \\
More than once & 3 & 18 & 40 \\
\hline
\end{tabular}

\subsection{2.- Public Services}

Public services are very limited. The colonists do not have electricity, water supply, or sewerage facilities. The road network is limited and basically unusable during the rainy season. The colonists received only limited health and school services. The most important health services are provided only in Ouro Preto or in Ji-Paraná; only elementary school is available elsewhere.

A good example of the failure in official support is the NUARs. The NUARs were planned to provide easier access to technical assistance, schools, health posts, 
commercial districts, recreation facilities, police, telephone lines and postal agencies (World Bank 1981). However, after 20 years the assistance is extremely restricted, $d$ only $44 \%$ of the colonists use the NUAR, primarily to sell their production or to buy food supplies or medication. In actuality, the NUARs became a location for people who were waiting for a piece of land, who were unemployed, or who had failed on their lots. 


\section{SUMMARY AND CONCLUSION}

After 20 years, the PIC Ouro Preto has a distinct spatial differentiation of lot sizes determined by the economic success of lots closest to the BR-364. Three components of changing ownership distribution occur in the area: maintenance of the original size, aggregation, and fragmentation of the lots. Lots adjacent to the BR-364 generally are aggregated into large pastures. This aggregation has occurred because these lots have been more profitable since transportation costs are reduced. Also these lots were among the first settled in the area and may represent the long-term trend.

The area of the PAD Urupá, which was only recently occupied, already presents the same trends. The colonists in Ouro Preto came basically from the south and southeastern regions of Brazil, many of them after several moves. Most of the colonists are applying their previous land-use practices, which include slash-and-burn agriculture without land preparation or management. As a result, $53 \%$ of the area has been deforested.

The governmental infrastructure either has collapsed or was never put into place, and there is not effective technical assistance. Most of the secondary and tertiary roads are impassable during the rainy season. The commercialization and storage of goods are not adequately provided. The NUARs are basically used for the acquisition of food supplies and medication.

The combination of the poor soil, inappropriate agricultural techniques, and lack of governmental support caused a high turnover in the land ownership and the abandonment of annual and perennial crops. Pasture with annual burnings has become the main form of land use ( $72 \%$ of the area cleared). Currently, colonists spend most of their money acquiring animals and improving the infrastructure (e.g., stables, fences).

The low economical return from crops reinforces the expansion of pasture. The increase of pasture (40-49\% in the 1980 s, $72 \%$ in 1991) shows that it may become the only form of land use in the region. Pasture also contributes to the aggregation of land because the poor colonists are obligated to sell their land. The necessity of obtaining larger areas for pasture and the availability of chain saws increase the potential for deforestation if alternative land-use practices are not promoted and employed. 


\section{ACKNOWLEDGEMENTS}

The authors would like to thank Eliomar Pereira da Silva Filho, of the Geography Department at FUNIR (Fundação Universidade de Rondonia), Eraldo A.T. Matricardi of the Secretary of Environmental Development (SEDAM) in Porto Velho, Charles L.P. Gomes and Ubiratan Rezende at the local offices of the SEDAM in Ouro Preto do Oeste and Mirante da Serra, and Alberto Quintans at the local office of SEDAM in Urupá, and Carlos Alberto Papini of the EMATER/RO in Ouro Preto do Oeste.

We would like to express our special thanks to those who have contributed the most information to this report, the colonists of the PIC Ouro Preto and PAD Urupá.

The comments of R. V. O'Neill and D. Jones on the manuscript were extremely useful. Chris Dearstone and Bob Frohn did the geographic information studies for the project.

This research is sponsored by ORNL Director's R\&D Fund through the Global Environmental Studies Center. This is Publication 3850, Environmental Sciences Division of the Oak Ridge National Laboratory, managed for the U.S. Department of Energy, under contract DE-AC05-840R21400 with Martin Marietta Energy Systems, Inc. 


\section{REFERENCES}

Browder, J. 1990. Desenvolvimento Regional e Conservaçăo de Florestas Tropicais em Rondonia. Observaçōes preliminares do Projeto de Pesquisa Rondonia. Brasil 17 de Junho- 12 de Agosto de 1990.

Coy, M. 1987. Rondonia: fronteira pioneira e o programa POLONOROESTE. $O$ processo de diferenciaçđo sócio-economica na periferia e os limites do planejamento público. In Kohlheppg and Schrader (eds): Homem e Natureza na AmazOnia, pp.253-70, Tubinguen, Germany.

Coy, M. 1989. Proceso de ocupacion y desarollo regional de la frontera pionera Rondonia (Amazonia Brasilena). Sobre las consecuencias de la politica de colonización agrória. Actas Latinoamericanas de Varsóvia, Tomo 7, Warsawa, pp. 169-208.

DNPM/RADAMBRASIL. 1978. Folha SC.20 Porto Velho; geologia, geomorfologia, pedologia, vegetaçăo e uso potencial da terra, Rio de Janeiro.

Fearnside, P. M. 1983. Land use trends in the Brazilian Amazon region as factors in accelerating deforestation. Environ. Cons. 19:141-48.

Fearnside, P. M. 1986. Human Carrying Capacity of the Brazilian Rainforest. Columbia University Press, Irvington, New York.

Frohn, R. C., V. H. Dale and B. D. Jimenez. 1990. Colonization, Road Development and Deforestation in the Brazilian Amazon Basin of Rondonia. ORNL/TM 11470, Oak Ridge National Laboratory.

INCRA. 1982. Relatório de Atividades do PIC Ouro Preto.

Jordan, C. F. 1987. Amazonian Rain Forests: Ecosystem Disturbance and Recovery. Ecological Studies 60. Springer-Verlag, New York.

Leite, L. L., and P. A. Furley. 1985. Land Development in the Brazilian Amazon with particular reference to RondOnia and Ouro Preto colonization project. pp. 119 40. In Hemming (ed.), Change in the Amazon Basin Volume II. The Frontier After a Decade of Colonization. Manchester University Press, Manchester, U.K. 
Lena, P. 1982. Dinamica da estrutura agrária e o aproveitamento dos lotes em um projeto de colonização de Rondonia. Anais do seminário "Expansăo da fronteira Agropecuária e Meio Ambiente da América Latina": Brastlia, 10 a 13 de Novembro de 1981. 29/1-9/35. Universidade de Brasala. Departamento de Economia, Braslia.

Machado, L. O. 1991. Frontera Agricola en la Amazonia Brasilena. VI Coloquio de Geografia Geral, Outubro, Madrid.

Malingreau, J., and C. J. Tucker. 1988. Large scale deforestation in the southeastern Amazon Basin of Brazil. Ambio 17:49-55.

Millikan, B. H. 1988. The dialectics of devastation: Tropical deforestation, land degradation, and society in Rondonia, Brazil. M.A. thesis, University of California, Berkeley.

Molofosky, J., C. A. S. Hall, and N. Myers. 1986. A comparison of tropical Forest Surveys. DOE/NB-0078. Washington, D.C.

Santos, B. A. 1983. Amazonia: Potencial mineral e perspectivas de desenvolvimento. T.A. Queiróz (ed.), São Paulo.

Stone, T. A, F. Brown, and G. M. Woodwell. 1991. Estimation by remote sensing of deforestation in Central Rondonia, Brazil. Forest Ecology and amd Management 38:291-304.1

World Bank 1981. Brazil: Integrated development of the Northwest frontier. World Bank, Washington, D.C. 
APPENDIX

INTERVIEW FORM

Tenant's Name

Tenant's Age

Family: \# men
Date of interview

\#women

\#Children

Arrival in Rondonia (yr)

Arrival on lot (yr)

Share-Cropper or owner

Lot size (ha)

Lot location

Position

Table 1. What is the distance from your house to the market $(\mathrm{km})$ ?

\begin{tabular}{||l|l|l|l|l||}
\hline Market & Total & Paved Road & Good dirt road & Bad dirt road \\
\hline Ji Parana & & & & \\
\hline Ouro Preto & & & & \\
\hline Other & & & & \\
\hline
\end{tabular}

Whec financing was used to acquire lot: cash( ), bank financing( ), other( )

What was your previous occupation?

FARMER: Owner/operator( ), Share-renter( ), or Fixed renter( )

URBAN OR. TOWN WORKER（）, UNEMPLOYED（）

RURAL NON-AGRICULTURAL WORKER( ), LAND-LESS FARMER/LABORER( ), OTHER( )

Where did you previously live?

RondOnia( ), NE Brazil( ), SE Brazil( ), Other( ),

State

How many lots did you live on in Rondonia before this lot?

Any soils information?

Source? 
Tenant's Name Date of interview

Table 2. Land use history (by alqueires or \%)

\begin{tabular}{|c|c|c|c|c|c|c|}
\hline \multirow[t]{3}{*}{$\begin{array}{l}\text { Year } \\
\text { on lot }\end{array}$} & \multirow{3}{*}{$\begin{array}{l}\text { Time } \\
\text { to } \\
\text { clear } \\
\text { lot } \\
\text { (days) }\end{array}$} & $\begin{array}{l}\text { Number } 0^{\prime} \text { xeople } \\
\text { helping tc c. ar the } \\
\text { lot }\end{array}$ & \multirow[t]{2}{*}{ Amount Cleared } & \multirow[t]{2}{*}{$\begin{array}{l}\text { Dense } \\
\text { Forest }\end{array}$} & Savannah & \multirow[t]{2}{*}{$\begin{array}{l}\text { Open } \\
\text { forest }\end{array}$} \\
\hline & & \multirow{2}{*}{$\overline{\text { Family } \quad \text { Non-family }}$} & & & & \\
\hline & & & Al & Al \% & $A \mathbf{l}$ & Al \% \\
\hline \multicolumn{7}{|l|}{ First } \\
\hline \multicolumn{7}{|l|}{ 2nd } \\
\hline & & & & & & \\
\hline & & & & & & \\
\hline & & & & & & \\
\hline & & & & & & \\
\hline & & & & & & \\
\hline & & & & & & \\
\hline & & & & & & \\
\hline & & & & & & \\
\hline & & & & & & \\
\hline & & & & & & \\
\hline $\begin{array}{l}\text { Cuirent } \\
(\end{array}$ & & & & & & \\
\hline
\end{tabular}

What kinds of tools do you use to clear the lot?

Axes( ), Chain-saw( ), Shovels( ), Other( )

How do you acquire the equipment?

$$
\text { Own( ), Rent( ), Borrow( ), Barter( ) }
$$

Has any decline in productivity of annual crops been obscrved? 
Tenant's name

Date of interview

Table 3. Land preparation

\begin{tabular}{||l|l|l|l|l|l||}
\hline Frequency & $\begin{array}{l}\text { Slash and } \\
\text { Burn }\end{array}$ & Manure & Lime & $\begin{array}{l}\text { Rotate } \\
\text { Crops }\end{array}$ & $\begin{array}{l}\text { Other } \\
\text { (specify) }\end{array}$ \\
\hline First yr. & & & & & \\
\hline $\begin{array}{l}\text { One yr. (other } \\
\text { than 1st) }\end{array}$ & & & & & \\
\hline Every yr. & & & & & \\
\hline $\begin{array}{l}\text { Two yrs. or } \\
\text { more }\end{array}$ & & & & & \\
\hline Never & & & & & \\
\hline
\end{tabular}

${ }^{3}$ Give years each portion is used.

Table 4. What costs are incurred in operating this lot?

\begin{tabular}{|l|l|l|}
\hline ITEM & Estimated costs-rented items & $\begin{array}{l}\text { Estimated Costs- purchased } \\
\text { items }\end{array}$ \\
\hline Mechanized equipment & & \\
\hline Hand equipment & & \\
\hline Animals & & \\
\hline $\begin{array}{l}\text { Team of animals with } \\
\text { operator }\end{array}$ & & \\
\hline Purchased seed & & \\
\hline Labor & & \\
\hline Fertilizer & & \\
\hline Insecticide/pesticide & & \\
\hline other & & \\
\hline
\end{tabular}

Table 5. Tenure information

\begin{tabular}{||l|l|l|l|l|l||}
\hline ITEM & \multicolumn{2}{|l|}{ Rent Land } & Share & Land & $\begin{array}{l}\text { Input } \\
\text { Costs }\end{array}$ \\
\hline Owner/operator & & & & & \\
\hline Renter & & & & & \\
\hline
\end{tabular}


Tenant's name

Date of interview

Table 6. Revenue per unit of product during previous year.

\begin{tabular}{|c|c|c|c|c|c|c|}
\hline Product & Alqueires & $\begin{array}{l}\text { Total } \\
\text { yield } \\
\text { (bags) }\end{array}$ & $\begin{array}{l}\text { Amount } \\
\text { sold } \\
\text { (bags) }\end{array}$ & $\begin{array}{l}\text { Where } \\
\text { sold" }\end{array}$ & $\begin{array}{l}\text { Method of } \\
\text { transport }^{b}\end{array}$ & \\
\hline \multicolumn{6}{|l|}{ All annuals } & \\
\hline \multicolumn{6}{|l|}{ Vegetables } & \\
\hline \multicolumn{6}{|l|}{ Rice } & \\
\hline \multicolumn{6}{|l|}{ Beans } & \\
\hline \multicolumn{6}{|l|}{ Manioc } & \\
\hline \multicolumn{6}{|c|}{ All perennials } & \\
\hline \multicolumn{6}{|l|}{ Cocoa } & \\
\hline \multicolumn{6}{|l|}{ Banana } & \\
\hline \multirow{2}{*}{\multicolumn{7}{|c|}{ Fruits }} \\
\hline & & & & & & \\
\hline All Pasture & & & & & & $\begin{array}{l}\text { Number of } \\
\text { animals }\end{array}$ \\
\hline Milk cows & & $\begin{array}{l}\text { liters/ } \\
\text { day }\end{array}$ & & & & \\
\hline Beef cows & & heads & & & & \\
\hline Poultry & & $\begin{array}{l}\text { heads } \\
\text { eggs }\end{array}$ & & & & \\
\hline Pigs & & heads & & & & \\
\hline
\end{tabular}

- Ji Parana, Ouro Preto (if sold at front door, indicate location of buyer)

'Symbols: $\mathrm{B}=$ bus, $\mathrm{OT}=$ own truck, $\mathrm{T}=$ truck belonging to someone else, $\mathrm{W}=$ walked and carried, $\mathrm{BC}=$ bicycle, $\mathrm{O}=$ other

List other major crops:

List other animals raised: 
Tenant's name

Date of interview

\section{Sociological questions}

Table 7. Technical assistance

\begin{tabular}{||l|l|l|l|}
\hline Frequency & EMBRAPA & EMATER & Other \\
\hline Never & & & \\
\hline Once & & & \\
\hline More than once & & & \\
\hline
\end{tabular}

Services available ( $\mathrm{Y}$ or $\mathrm{N})$

$\begin{array}{ll}\text { Water supply( ) Electricity( ) } & \text { School( ) } \\ \text { Telephone( ) } & \text { Health Center( ) (distance - } \\ \end{array}$

Main problems to make coditions better (rank, 1=most imp.):

$\begin{array}{ll}\text { Roads( ) } & \text { Transportation( ) } \\ \text { Education( ) } & \text { Technical supporth( ) }\end{array}$

Do you use the NUAR? How?

Are you planning to leave your lot? Why?

\section{Where?}

Why did you decide to buy this particular lot? (or settle if sharecropper)

What majoi problen s occured during the installation period?

$$
\begin{aligned}
& \text { illness( ) transportation( ) } \\
& \text { lack of technical assistance( ) other( ) }
\end{aligned}
$$

What kinds of illness occured in your family?

$$
\begin{aligned}
& \text { Malaria( ) Leishmanioses( ) erysipelas( ) } \\
& \text { cholera( ) other( ) specify }
\end{aligned}
$$

How many days were you or members of your family out of work during the past year?

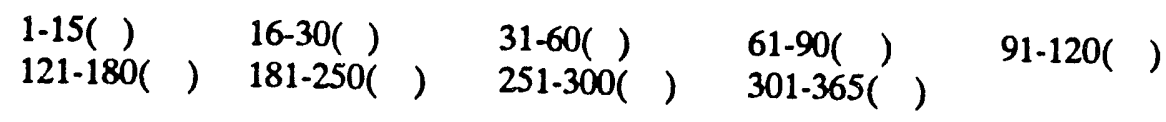




\section{INTERNAL DISTRIBUTION}

ORNL/TM-12062

1. S. I. Auerbach, 1505, MS-6036

2. L. D. Bates, K-1009, MS-7169

3. R. B. Clapp, 1505 , MS- 6038

4. J. B. Cannon, $4500 N$, MS-6189

5. T. A. Chatfield, 1505 , MS- 6035

6. J. H. Cushman, 1503, MS- 6352

7. R. B. Cushman, 1000 , MS-6335

8.-38. V. H. Dale, 1505 , MS-6038

39. W. R. Emanuel, 1000, MS-6335

40. D. E. Fowler, 1505, MS-6035

41. R. H. Gardner, 1505, MS-6036

42. R. L. Graham, 1505 , MS-6038

43. C. W. Gehrs, 1505 , MS-6036

44. E. L. Hillsman, 4500 N, MS-6206

45. S. G. Hildebrand, 1505, MS-6035

46. W. Hudson, 1506, MS-6034

47. C. T. Hunsaker, 1505 , MS-6038

48. D. W. Jones, $4500 \mathrm{~N}$, MS-6205

49. J. Kahn, 4500 N, MS-6205

50. P. Kanciruk, 0907, MS-6490

51. A. W. King, 1000, MS-6335
52. G. Marland, 1000, MS-6335

53. R. V. O'Neill, 1505, MS-6036

54. W. M. Post, 1000, MS-6335

55. D. E. Reichle, 4500 N, MS-6253

56. F. E. Sharples, 1505, MS- 6036

57. D. S. Shriner, 1505, MS-6038

58. R. Shelton, $4500 \mathrm{~N}$, MS-6205

59. F. Southworth, 4500N, MS-6206

60. S. H. Stow, 1505, MS-6038

61. R. I. Van Hook, 1505, MS-6035

62. H. Van Miegroet, 1505, MS-6038

63. T. J. Wilbanks, 4500N MS-6184

64. L. Wright, 1503, MS-6352

65. CDIARP Files

66. Central Research Library

67.-81. ESD Library

82.-83. Laboratory Records Department

84. Laboratory Records, RC

85. ORNL Patent Office

86. ORNL Y-12 Technical Library

\section{EXTERNAL DISTRIBUTION}

87. Bertha K. Becker, Departamento de Geografia, Instituto de GeocienciasU.F.R.J., Ilha do Fundåo, Rio de Janeiro - R.J., C.E.P. 21949, BRAZIL

88. Alpina Begossi, Depto c/o Ecologia - IB UFRJ C. P. 68020, Rio De Janeiro, RJ 21941, Brazil

89. R. Bierregaard, Stop 180, Room W-300, Smithsonian Institute, Washington, DC 20560

90. Rizza Castelo Branco, Secretaria da Ciencia e Tecnologia/PR, Esplanada dos Ministérios, loco "E", 20. andar Brazllia, D.F. C.E.P. 70.000, Brazil

91. John Browder, Urban Affairs and Planning Program, Architecture Annex. 201, Virginia Polytechnic Institute, Blacksburg, VA 24061 
92. Foster Brown, Woods Hole Research Center, P. O. Box 296, Woods Hole, MA 02543

93. Sandra Brown, Department of Forestry, University of Illinois, 101 Mumford Hall, 1301 W. Gregory Drive, Urbana, IL 21801 (217-333-1643)

94. Luis Antonio Barreto de Castro, Director, Secretariat of Science and Technology, PR, Brasilia, DF, Brazil

95. Carlos Cerri, Centro de Energia Nuclear na Agricultura, Caixa Postal 96, Piracicaba, S.P., C.E.P. 13.400 , Brazil

96. Cláudio Monteiro Considera, IBGE- Departamento de Contas Nacionais, Av. Visconde de Niterói, 1246/13o., Mangueira, Rio de Janeiro, R.J., C.E.P. 20.941, Brazil

97. Mancio Lima Cordeiro, Universidade Federal do Acre, BR 364 km 04, Campus Universitário, Rio Branco, AC, Brazil

98. Laercio Couto, Universidade Federal De Vicosa, Departmento de Engenharia Florestal, 36570 Vicosa, Minas Gerais, Brazil

99. Alan Cross, The United Nations Environmmental Program, GRID, 6 Rue de la Gabelle, CH1227 Carouge, Geneva, Switzerland

100. Martin Coy, Scheefstrape 64, Geographisches Institut, Universitaet Tuebingen, Hoelderlinstrasse 12 D - 7400 Tubingen, Germany

101. José Dancé, Universidad Agracia La Molina, Facultad de Ciencias Forestales, Lima, Perú

102. Michael Dow, National Research Council, 2101 Constitution Avenue, N.W., Washington, DC 25023-1818

103. John Estes, Department of Geography, University of California, Santa Barbara, CA 93106

104. Phillip M. Fearnside, Instituto Nacional de Pesquisas da Amazonia, Caixa Postal 478,69.000 Manaus, Amazonas, Brazil

105. Nelson Fernandes, Departament of Geology and Geophysics, University of California, Berkeley, CA 94720

106. Luis Goes Filho, Departmento de Recursos Naturais e Estudos Ambientais, Instituto Brazilero de Geografia e Estatistica (IBGE), Brazilian Institute of Geography and Statistics, Rua Paulo Fernandes, no. 24, Praca da bandeira 20271, Rio de Janeiro -RJ, Brazil 
107. Eliomar Pereira da Silva Filho, Caixa Postal 346, Porto Velho, RO, C.E.P. 78.900, Brazil

108. Emmanoel Vieira da Silva Filho, Departamento de Geoquímica, Universidade Federal Fluminense, Niterói,R.J., C.E.P. 24.210 Brazil

109. Paulo Sérgio Moreira da Fonseca, Banco Nacional de Desenvolvimento, Av. República do Chile, 100/13o., Rio de Janeiro, R.J., C.E.P. 20.001, Brazil

110. Ron Forestra, Department of Geography, University of Tennessee, Knoxville, TN 37996-1420

111. J. F. Franklin, Bloedel Professor of Ecosystem Analysis, College of Forest Resources, University of Washington, Anderson Hall AR-10, Seattle, WA 98195

112. Robert Frohn, Department of Geography, University of California, Santa Barbara, CA 93106

113. Robert Goodland, The World Bank, 1818 H. Street N.W., Washington, D.C. 20433

114. Alan Grainger, University of Salford, Department of Geography, Salford, N:- 4 WT, England

115. Thurman Grove, North Carolina State University, College of Agriculture and Life Sciences, Raleigh, NC 27695-7695

116. Michael Gwynne, Director, Global Environmental Systems, United Nations Environmental Systems, United Nations Environmental Program, P.O. Box 30552, Nairobi, Kenya

117. Charles Hall, College of Environmental Sciences and Forestry, State University of New York, Syracuse, NY 13210

118. R. C. Harriss, Institute for the Study of Earth, Oceans, and Space, Science and Engineering Research Building, University of New Hampshire, Durham, NH 03824

119. Kate Heaton, Bruce Company, Suite 1100 , Sixth Street, u W, Washington, DC 20024

120. Niro Higuchi, Coordenaçăo de Planejamenta, INPA, C.E.P. 69011, Manus, Brazil

121. Vitor Afonso Hoeflich, Centro Nacional de Pesquisa de Florestas, Caixa Postal 3319, Curitiba, P.R. C.E.P. 80.001, BRAZIL 
122. Sabastiao Jengen, Instituto Brazilero Medio Ambiente (IBAMA), de Recursos Naturales Renovables, Brazilian Environmental Institute of Renewable Resources, Departmento Pesquisas Forestal, Caixa Postal 07-0037, Brasilia DF, Brazil 70359

123. George Y. Jordy, Director, Office of Program Analysis, Office of Energy Research, ER-30, G-226, U.S. Department of Energy, Washington, DC 20545

124. D. Johnson, Graduate School of Planning, The University of Tennessee, 1618 Cumberland Avenue, Knoxville, TN 37996-3300

125. Armond Joyce, Earth Resources Laboratory, John C. Stennis Space Center, Stennis Space Center, MS 39629

126. Luiz Drude de Lacerda, Departamento de Geoquímica, Universidade Federal Fluminense, Niterói, R.J., Brazil

127. J. P. Lanley, Forestry Division, FAO, via Terme di Caracalla, Rome, Italy

128. Marilia Locotelli, EMBRAPA, Centro de Pesquisa Agro-Florestal de Rondonia, CE PAF/RO BR 364 KM 5.5 - CX Postal 406, Porto Velho, RodOnia, C.E.P. 78.900, Brazil

129. Felipe Loureiro, College of Engineering, Department of Civil Engineering, 233 Perkins Hall, University of Tennessee, Knoxville, TN 37996

130. Tom Lovejoy, Smithsonian Institute, Castle Building 320, Washington, DC 20560

131. Ariovaldo Luchiari, Jr., Centro de Pesquisa Agropecuaria dos Cerrados (EMRAPA), KM 18, Br-020, Cx Postal 70/0023, CEP: 73,300, Planaltina-DF, Brazil

132. Ariel Lugo, Institute of Tropical Forestry, Call Box 25000, Rio Piedras, Puerto Rico 00928-2500

133. Lia O. Machado, Departamento de Geografia, Instituto de GeocienciasU.F.R.J., Ilha do Fundão, Rio de Janeiro - R.J., C.E.P. 21949, BRAZIL

134. Jean-Paul Malingreau, Remote Sensing Programme, Commission of the European Communities, Joint Research Centre, Ispra Establishment, I-21020 Ispra (Varese), Italy

135. Luiz Antonio Martinelli, Centro de Energia Nuclear na Agricultura, Caixa Postal 96, Piracicaba, S.P., C.E.P. 13.400, Brazil 
136. Eduardo de Souza Martins, Rua Nacoes Unidas 169, 69900 Rio Branco, Acre, Brazil

137. Eraldo Aparecido T. Matricardi, Rua 04, Quadra 04, Casa 19, Jardim Acapul, 78900 Porto Velho, C.E.P 78900, Rondonia, Brazil

138. Frank McCormick, University of Tennessee, Graduate Program in Ecology, 691 Dabney Hall, University of Tennessee, Knoxville, TN 37996-1610

139. John R. McKenna, Senior Resource Planner, The World Bank, 1818 H. Street, NW, Washington, DC 20433

140. Ernesto Medina, Instituto Venezolano de Investigaciones Cientificas (IVIC), Centro de Ingenieria Ambiental, Caracas, Venezuela

141. John Melack, Department of Biological Sciences, University of California, Santa Barbara, CA 93106

142. William Z. de Mello, University of New Hampshire, E.O.S./S.E.R.B., Durham, NH 03824

143. Brent Millikan, University of California at Berkley, Department of Geography, 501 Earth Science Building, Berkley, CA 94720

144. Luiz Molion, University of Manaus, Department of Ecology, Manaus, Amazonas, Brazil

145. Harold Mooney, Department of Biological Sciences, Stanford University, Department of Biologv, Stanford, CA 94305

146. Emilo Moran, Indiana University, Department of Anthropology, School of Public and Environmental Affairs, Bloomington, IN 47401

147. Ronaldo S. Motta, IPEA- Instituto de Economia Aplicada, Av. Pres. Antonio Carlos, 51/17o., Rio de Janeiro, R.J., C.E.P. 20.020, BRAZIL

148. Antonio Aparecido Mozeto, Departamento de Química, U.F.SCar, Caixa Postal 676, Såo Carlos, S.P., C.E.P. 13.560, Brazil

149. M. Joaquina Pires O'Brien, Department of Ecologia, Museu Paraense E. Goeldi, 66.000 Belém, Pará, Briazil

150. Eduardo Felipe Ohana, Instituto Brasileiro para Pesquisa em Economia Aplicada, SBS Edifício BNDS, sala 703, Brasilia, D.F., C.E.P. 70.076, Brazil

151-161. Marcos Pedlowski, 1700 Plank Drive, Blacksburg, Virginia 24060 
162. R. H. Olsen, Professor, Microbiology and Immunology Department, University of Michigan, Medical Sciences II, \#5605, 1301 East Catherine Street, Ann Arbor, MI 48109-0620

163. Jerry Olson, Global Associates, Eblen Cave Road, Box 361A, Route 2, Lenoir City, TN 37771

164. Alvaro Ramon C. Ovalle, Departamento de Geoquímica, Universidade Federal Fluminense, Niteroi,R.J., C.E.P. 24.210 Brazil

165. Christine Padoch, New York Botanical Gardon, Bronx, NY 10458

166. Guillermo Palacios, Universidade Federal Rural do Rio de Janeiro, CPDA UFRRJ, Av. Pres Vargas, 4178, Rio de Janeiro, R.J., C.E.P. 20.031, Brazil

167. Francisco Palmieri, Empresa Brazilera de Pesquisas Agropecurias (EMBRAPA), Servicio Nacional De Levantamento, e Conservacao de Solos, Rua Jardim Botanico 1024 - 22460, Rio de Janeiro - RJ, Brazil

168. Clara Pandolfo, Department of Natural Resources, Superintendencia de Desenvolvimiento de Amazonia (SUDAM) Superintendent for Amazonian Development, Av. Almirante Barroso 426, Belem 66.000 Para, Brasil

169. Ari Patrinos, Director, Environmental Sciences Division, Office of Health and Environmental Research, ER-74, U.S. Department of Energy, Washington, DC 20585

170. Paulo Gustavo do Prado Pereira, DEPLAN, SEMAM/PR, Esplanada dos Ministérios, Brasilia, D.F., BRAZIL

171. Bruce Ralston, Geography Department, University of Tennessee, Knoxville, TN 37996

172. Carlos Eduardo Rezende, Laboratórid de Radioisótopos, IBCCF - CCS, U.F.R.J., Ilha do Fundăo, Rio de Janeiro, R.J., C.E.P. 21941, Brazil

173. Jeff Richey, School of Oceanography, University of Washington, Seattle, WA 98195

174. John Richards, Department of History, Duke University, 6727 College Station, Durham, NC 27708

175. Alberto W. Setzer, Instituto de Pesquisas Espaciais-INPE, C. Postal 515, 12201 - S.J. Campos, SB, Brazil

176. Jorge Xavier da Silva, Departamento de Geografia, Instituto de GeocienciasU.F.R.J., Ilha do Fundåo, Rio de Janeiro - R.J., C.E.P. 21949, Brazil 
177. K. D. Singh, Forestry Division, FAO, via Terme di Caracalla, Rome, Italy

178. Rajindra Kaur Singh, Rua Cecilia Mereles 98 Taboa, 80000 Curitiba, Parana, Brazil

179. David Skole, Complex Systems Research Center, Science and Engineering Building, University of New Hampshire, Durham, NH 03824

180. Thomas Stone, Woods Hole Research Center, P.O. Box 296, Woods Hole, MA 02543

181. Compton J. Tucker, NASA Goddard Spaceflight Center, Laboratory for Terrestrial Physics, ATTN: 623, Greenbelt, MD 20771

182. Sandra Turner, Division of Wildlife \& Ecology, CISRO, P.O. Box 84, Lyneham, ACT 2606, Australia

183. Chris Uhl, Centrode Pesquisa Agroflorestal do Trópico Umido, EMBRAPA, Belém, Pará, Brazil

184. José Eli Savóia da Veiga, Faculdade de Admnistração de Empresas e Economia, Universidade de São Paulo São Paulo, S.P., 01.000, Brazil

185. Reinaldo Victoria, Centro de Energia Nuclear na Agricultura, Caixa Postal 96, Piracicaba, S.P., C.E.P. 13.400 , Brazil

186. Marv Waterstone, University of Arizona, Tuscon, AZ 85721

187. Frank J. Wobber, Environmental Sciences Division, Office of Health and Environmental Research, Office of Energy Rsearch, ER-74, U.S. Department of Energy, Washington, DC 20585

188. Office of Assistant Manager for Energy Research and Development, U.S. Department of Energy Oak Ridge Field Office, P.O. Box 2001, Oak Ridge, TN 37831-8600

189-199. Office of Scientific and Technical Information, P.O. Box 62, Oak Ridge, TN 37831 

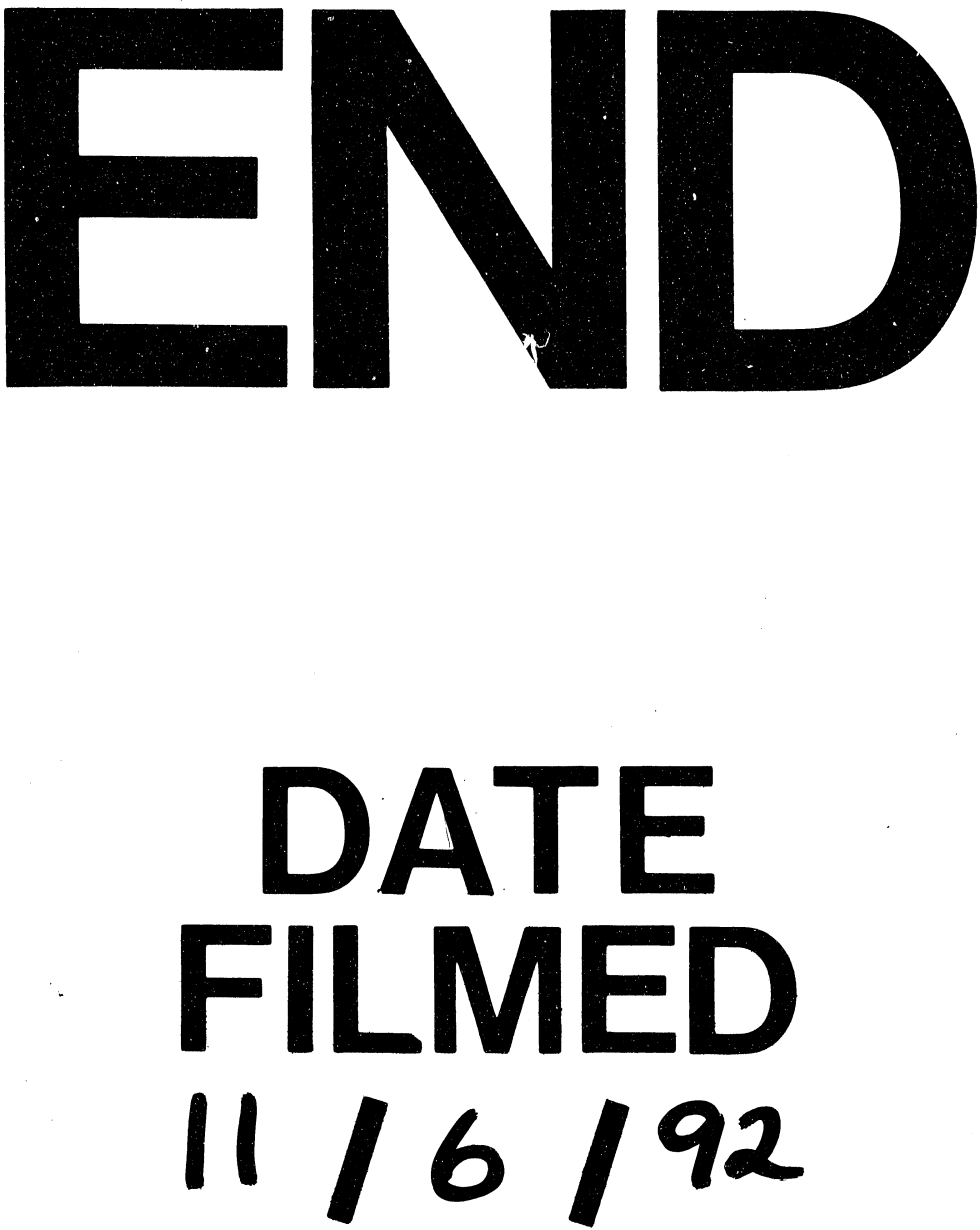

1 
